\title{
Pengaruh BPK, Karakteristik Pemerintah dan Indeks Pembangunan Manusia terhadap Tingkat Korupsi Pemerintah Daerah di Indonesia
}

\author{
Verawaty \\ Universitas Bina Darma \\ Email:verawaty@binadarma.ac.id \\ Intan Puspanita \\ Universitas Bina Darma \\ Email: intan.puspanita@binadarma.ac.id \\ Endah Sularti \\ Universitas Bina Darma \\ Email: endahsularti12@gmail.com
}

\begin{abstract}
This research was aimed to obtain empirical evidence about the influence of audit findings, follow-up to the results of recommendations and audit opinions on the level of local government corruption in Indonesia with the size of the government, capital expenditure and human development index as a control variable. The research sample was 30 provincial governments that met the criteria. The analysis technique was quantitative by using multiple linear regression. The results indicated that only follow-up recommendations had an influence on the level of corruption. The implication is that the regional government needs to be aware of violations of the laws and regulations during the process of government administration, especially for actions that can cause state losses.
\end{abstract}

Keywords: Corruption; audit findings; follow-up recommendations; audit opinions; government measures; capital expenditure; human development index

\begin{abstract}
Abstrak
Penelitian ini bertujuan untuk memperoleh bukti empiris mengenai pengaruh temuan audit, tindak lanjut hasil rekomendasi dan opini audit terhadap tingkat korupsi pemerintah daerah di Indonesia dengan ukuran pemerintah, belanja modal dan indeks pembangunan manusia sebagai variabel kontrol. Sampel penelitian adalah 30 pemerintah provinsi yang memenuhi kriteria. Teknik analisis yang digunakan adalah kuantitatif dengan menggunakan regresi linear berganda. Hasil penelitian ini menunjukkan bahwa hanya tindak lanjut rekomendasi memiliki pengaruh terhadap tingkat korupsi. Implikasi penelitian ini adalah Pemerintah daerah perlu mewaspadai adanya pelanggaran terhadap peraturan perundang-undangan selama proses penyelenggaraan pemerintahan, terutama untuk tindakan yang dapat menimbulkan kerugian negara.

Kata kunci: Korupsi; temuan audit; tindak lanjut hasil rekomendasi; opini audit; ukuran pemerintah; belanja modal; indeks pembangunan manusia
\end{abstract}

\section{Pendahuluan}

Korupsi merupakan penyebab hambatan pertumbuhan, perkembangan dan kemakmuran rakyat pada berbagai negara (Sharma \& Mitra, 2015). Adanya korupsi pada pemerintahan, maka berpengaruh pada tingkat investasi yang rendah yang berdampak pada penurunan tingkat ekonomi dan pengangguran yang tinggi (Setyaningrum, 2015). Penggunaan indeks persepsi korupsi juga sering digunakan sebagai indikator keberhasilan upaya pemberantasan korupsi di banyak negara di dunia (Transparency International Indonesia, 2016). Selama beberapa tahun terakhir, penyelenggaraan pemerintahan secara umum dan pembangunan secara khusus telah mendapat sejumlah kritikan mendasar, tidak hanya dari dalam negeri tetapi juga dari komunitas internasional. Transparency International misalnya, melakukan peringkat 
negara yang mengalami masalah besar dalam sektor publiknya, mengidentifikasi Indonesia sebagai negara yang masih bermasalah dalam korupsi di dunia.

Transparansi International dipilih karena keterbukaan data dan lebih ke arah korupsi secara keseluruhan dengan melihat ukuran Indeks Persepsi Korupsi (IPK) yang diperoleh dari Transparansi International. Menurut (Masyitoh, Wardhani, \& Setyanigrum, 2015), tingginya tingkat korupsi negara membuktikan buruknya penyelenggaraan pemerintahan di negara tersebut karena peran pemerintah dalam mengalokasikan sumber daya publik dapat terdistorsi dengan adanya fenomena korupsi.

Tabel 1

Indeks Persepsi Korupsi Negara-Negara ASEAN

\begin{tabular}{|c|c|c|}
\hline Negara & $\begin{array}{c}\text { Tahun 2016 } \\
\text { (Skor IPK) }\end{array}$ & $\begin{array}{c}\text { Tahun 2017 } \\
\text { (Skor IPK) }\end{array}$ \\
\hline Kamboja & 22 & 21 \\
\hline Myanmar & 28 & 30 \\
\hline Laos & 30 & 29 \\
\hline Vietnam & 32 & 35 \\
\hline Filipina & 35 & 34 \\
\hline Thailand & 35 & 37 \\
\hline Indonesia & $\mathbf{3 6}$ & $\mathbf{3 7}$ \\
\hline Malaysia & 49 & 47 \\
\hline Brunei & 58 & 62 \\
\hline Singapura & 84 & 84 \\
\hline
\end{tabular}

Sumber: (Transparency International, 2016)

Berdasarkan Indeks Persepsi Korupsi (IPK) Indonesia pada tahun 2016 berada pada peringkat 4 di kawasan ASEAN. Negara dengan IPK tertinggi di kawasan Asia Tenggara adalah negara Singapura dengan skor 84, dan berada pada posisi 7 tingkat dunia. Riset yang dilakukan Transparency International mencatat bahwa skor IPK Indonesia 37, naik 1 poin dari tahun sebelumnya 36. Indonesia berada di peringkat 90 dari 176 negara yang disurvei. Naiknya indeks persepsi korupsi ini mengindikasikan bahwa pemberantasan korupsi masih berjalan meskipun lambat sehingga cukup berat untuk mencapai peringkat 50 yang ditargetkan. Survei terbaru yang dilakukan Transparency International, Indonesia berada di peringkat 96 (dari 180 negara di dunia) pada IPK 2017. Dari daftar indeks skor yang diperoleh Indonesia adalah 37, masih sama skor yang diperoleh dari tahun sebelumnya.

Fakta di atas menunjukkan masih tingginya jumlah kasus korupsi di Indonesia. Hal ini dikuatkan oleh laporan tren korupsi semester I tahun 2015 dari Indonesia Corruption Watch (ICW, 2015), selama semester I tahun 2015 terdapat 308 kasus korupsi memasuki tahap penyidikan yang melibatkan 590 orang tersangka dan nilai kerugian negara mencapai 1,2 triliun. Terjadi kenaikan jumlah kasus pada semester pertama tahun 2015 dimana rata-rata kasus korupsi yang masuk tahap penyidikan per semester adalah 253 kasus, sedangkan jumlah kasus yang ditindak pada semester I tahun 2015 adalah 308 kasus. Kajian ICW pada semester I tahun 2016 (ICW, 2016) menunjukkan korupsi di daerah mencapai 205 kasus (97\%), sebaliknya di level nasional hanya lima kasus (2\%). 
Berdasarkan lembaga pelaku kasus korupsi, ICW juga mencatat birokrasi daerah menjadi yang tertinggi dengan 145 kasus korupsi, menyusul lembaga non-kementerian, BUMN, KPU, kecamatan/kelurahan, universitas, dan DPRD. Hal ini membuktikan bahwa hingga saat ini, pemerintah daerah masih menjadi episentrum kasus korupsi. Dengan demikian, semakin luasnya pelaksanaan otonomi daerah, perlu diimbangi dengan pengawasan yang memadai agar tidak menimbulkan korupsi, kolusi, nepotisme (KKN) baru atau memindahkan KKN dari tingkat pusat ke daerah.

Salah satu penyebab utama dari keadaan di atas adalah semakin meluasnya korupsi, kolusi, dan nepotisme (KKN) di kalangan lembaga pemerintahan. Kenyataan selama ini menunjukkan meluasnya KKN di seluruh instansi pemerintah, baik di tingkat pusat maupun daerah. Upaya pemerintah dalam pemberantasan korupsi dilaksanakan melalui beberapa kebijakan berupa peraturan perundang-undangan dari yang tertinggi yaitu Undang-Undang Dasar 1945 sampai dengan Undang-Undang Nomor 20 tahun 2001 tentang Pemberantasan Tindak Pidana Korupsi (Republik Indonesia, 2001). Selain itu, pemerintah juga membentuk institusi pemeriksa untuk mencegah penyalahgunaan dan ketidakefisienan penggunaan sumber daya. Fungsi pemeriksaan dapat dilaksanakan melalui proses audit yang berperan dalam memberikan informasi atau mendeteksi kecurangan, seperti adanya pengeluaran sumber daya publik yang berlebihan atau hilang (Olken, 2007).

Ada beberapa hal yang bisa mempengaruhi tingkat korupsi, di antaranya, temuan audit BPK, tindak lanjut rekomendasi hasil pemeriksaan, opini audit, ukuran pemerintah, belanja modal dan indeks pembangunan manusia. Keenam hal yang mempengaruhi tingkat korupsi tersebut, merupakan variabel yang saling berkaitan satu dengan yang lainnya dalam tingkat korupsi. Dengan demikian, tujuan penelitian ini adalah ini untuk memperoleh bukti empiris mengenai pengaruh hasil audit, opini audit, karakteristik pemerintah, dan indeks pembangunan manusia pada pemerintah daerah di Indonesia Pada penelitian ini, pemerintah provinsi dipilih sebagai objek penelitian karena output pelaksanaan tugas pemerintah provinsi adalah memberikan pelayanan kepada masyarakat. Komisi Pemberantasan Korupsi tahun 2014 dalam (Kompas, 2014) menyebutkan sektor pelayanan publik di Indonesia masih rawan korupsi dalam bentuk penyuapan, pemerasan, gratifikasi atau penyalahgunaan wewenang. Oleh karena itu, diperlukan dukungan teknologi informasi, komunikasi, pemeriksaan, karakteristik pemerintah dan tingkat pendidikan yang dapat meminimalkan tindakan korupsi.

\section{Literature Review}

\subsection{Temuan Audit terhadap Tingkat Korupsi}

BPK bukan hanya memberikan opini atas laporan keuangan, instansi ini juga memberikan laporan hasil pemeriksaan atas sistem pengendalian intern, dan laporan hasil pemeriksaan atas kepatuhan terhadap peraturan perundang-undangan. Kelemahan sistem pengendalian intern dan ketidakpatuhan terhadap ketentuan peraturan perundang-undangan yang dilaporkan BPK menunjukkan tingkat akuntabilitas laporan keuangan. Semakin banyak kelemahan sistem pengendalian intern dan ketidakpatuhan terhadap ketentuan peraturan perundang-undangan menunjukkan informasi keuangan yang disajikan dalam laporan keuangan tidak dapat diandalkan. (Huefner, 2011) menyatakan bahwa cara yang utama untuk mencegah terjadinya kecurangan yaitu dengan adanya sistem pengendalian intern 
yang kuat. Semakin banyak temuan kelemahan pengendalian internal akan meningkatkan kemungkinan terjadinya korupsi. Berdasarkan Huefner (2011), temuan audit atas sistem pengendalian intern dapat digunakan untuk mendeteksi adanya potensi kecurangan di lingkungan pemerintah daerah.

(Liu \& Lin, 2012), (Azhar \& Setyaningrum, 2015) serta (Yuliyana \& Setyaningrum, 2016) juga menyatakan bahwa temuan audit atas ketidakpatuhan pada perundangundangan berpengaruh positif terhadap tingkat korupsi. Semakin banyak temuan atas ketidakpatuhan pada perundang-undangan menunjukkan tingkat korupsi yang lebih tinggi. (Arifianti, Payamta, \& Sutaryo, 2013) telah membuktikan secara empiris bahwa ketidakpatuhan pemerintah daerah terhadap peraturan dan perundang-undangan memiliki dampak yang negatif dan signifikan terhadap penilaian kinerja. Pelanggaran terhadap peraturan yang telah ditetapkan menunjukkan buruknya kinerja penyelenggaraan pemerintahan di daerah tersebut.

\subsection{Tindak Lanjut Hasil Audit terhadap Tingkat Korupsi}

Tahapan pemantauan tindak lanjut atas rekomendasi yang diberikan oleh auditor penting untuk dilakukan agar rekomendasi yang diusulkan oleh auditor dapat diimplementasikan dengan baik oleh pemerintah daerah. Dengan melaksanakan apa yang telah direkomendasikan oleh auditor, maka pemerintah daerah telah berupaya untuk memperbaiki kesalahan dalam pertanggungjawaban penyelenggaraan negara. Menurut (Liu \& Lin, 2012), pembetulan setelah adanya proses audit lebih penting dari deteksi atas temuan audit itu sendiri karena upaya untuk melakukan pembetulan audit dapat meningkatkan efektivitas proses audit.

Pembetulan setelah proses audit merupakan suatu bentuk tanggung jawab dari pemerintah daerah atas kesalahan dalam pertanggungjawaban keuangan publik. Akuntabilitas dalam proses audit pemerintahan akan tercipta jika adanya penyelesaian dari hasil temuan audit supaya bermanfaat. (Liu \& Lin, 2012), (Azhar \& Setyaningrum, 2015) serta (Lukfiarini, 2018) mengemukakan bahwa tindak lanjut hasil audit berpengaruh negatif terhadap tingkat korupsi. Hasil serupa dikemukakan oleh (Masyitoh et al., 2015) serta (Yuliyana \& Setyaningrum, 2016) yang menyatakan tindak lanjut hasil audit berpengaruh negatif terhadap persepsi korupsi. Semakin banyak rekomendasi auditor yang ditindaklanjuti oleh pemerintah menunjukkan tingkat korupsi yang lebih rendah.

\subsection{Opini Audit terhadap Tingkat Korupsi}

Menurut Undang-Undang Nomor 15 Tahun 2004 tentang Pemeriksaan Pengelolaan dan Tanggung Jawab Keuangan Negara pasal 1 angka 11 (Republik Indonesia, 2004), opini audit negara adalah pernyataan profesional sebagai kesimpulan pemeriksa tentang tingkat kewajaran atas penyajian informasi di dalam laporan keuangan. Kriteria atas pemberian opini adalah kesesuaian dengan standar akuntansi pemerintahan, kecukupan pengungkapan (adequate disclosures), kepatuhan terhadap peraturan perundangundangan, dan efektivitas sistem pengendalian intern.

Pemeriksaan atas laporan keuangan dilakukan untuk memberikan pendapat/opini atas kewajaran informasi keuangan yang disajikan dalam laporan keuangan. Opini audit laporan keuangan menunjukkan tingkat kewajaran yang mencerminkan tingkat 
akuntabilitas laporan keuangan yang diyakini memberikan kontribusi dalam usaha mereduksi praktek korupsi. Hubungan antara opini audit dan kinerja pemerintah daerah telah dibuktikan secara empiris oleh (Ismunawan, 2016) dimana opini audit memiliki pengaruh terhadap korupsi pemerintah daerah. Penelitian ini didukung oleh (Masyitoh et al., 2015) yang menyatakan bahwa opini audit berpengaruh negatif terhadap persepsi korupsi. Semakin baik opini audit yang diperoleh menunjukkan semakin rendah potensi korupsi di lingkungan pemerintah daerah. Hasil serupa juga dinyatakan oleh (Rini \& Sarah, 2014) yang menyatakan bahwa terdapat kaitan antara opini yang diberikan oleh BPK RI dengan korupsi.

\section{Metodologi Penelitian}

\subsection{Populasi dan Sampel}

Secara umum, objek dalam penelitian ini adalah pemerintah daerah provinsi yang ada di Indonesia. Data dalam penelitian ini adalah data sekunder, yaitu data yang sumbernya diperoleh dari pihak lain. Data tersebut diperoleh dari berbagai instansi yang memberikan penilaian, pemeriksaan dan evaluasi serta instansi yang terkait dengan variabel-variabel penelitian. Data yang digunakan yaitu data laporan tahunan Kejaksaan Tinggi tahun 2015 (Kejaksaan Republik Indonesia, 2015), laporan IHPS (Ikhtisar Hasil Pemeriksaan Keuangan Semester) tahun 2015 (Badan Pemeriksa Keuangan, 2015), laporan indeks pembangunan manusia tahun 2015 (Badan Pusat Statistik, 2016). Pemilihan sampel menggunakan metode purposive sampling method. Sampel dalam penelitian ini adalah 30 provinsi di Indonesia yang memiliki kriteria yang dimiliki peneliti. Empat provinsi yang tidak menjadi sampel adalah Kalimantan Utara, Kalimantan Tengah, Sulawesi Barat dan Papua Barat karena tidak memiliki data tingkat korupsi serta tidak memiliki data IHPS. Berikut deskripsi pengambilan sampel penelitian:

Tabel 2

Deskripsi Penarikan Sampel Penelitian

\begin{tabular}{|c|l|c|}
\hline No & \multicolumn{1}{|c|}{ Keterangan } & Jumlah \\
\hline 1 & Jumlah pemerintah daerah provinsi & 34 \\
\hline 2 & Tidak memiliki laporan tahunan yang lengkap tahun 2015 & 0 \\
\hline 3 & $\begin{array}{l}\text { Tidak memiliki kelengkapan data dan informasi anggaran mengenai } \\
\text { variabel-variabel yang diteliti (data variabel y, yaitu tingkat } \\
\text { korupsi) }\end{array}$ & 4 \\
\hline Jumlah provinsi yang menjadi sampel penelitian & 30 \\
\hline
\end{tabular}

Sumber: Data diolah, 2018

Berdasarkan kriteria yang telah ditetapkan dengan metode purposive sampling tersebut, maka pemerintah daerah yang menjadi sampel penelitian ini yaitu ada 30 pemerintah daerah. Berikut nama-nama pemerintah daerah yang menjadi objek penelitian ini: 
Tabel 3

Sampel Penelitian

\begin{tabular}{|c|l|c|l|}
\hline No & Nama Provinsi & No & Nama Provinsi \\
\hline 1 & Aceh & 18 & Nusa Tenggara Barat \\
\hline 2 & Sumatera Utara & 19 & Nusa Tenggara Timur \\
\hline 3 & Sumatera Barat & 20 & Kalimantan Barat \\
\hline 4 & Riau & 21 & Kalimantan Selatan \\
\hline 5 & Jambi & 22 & Kalimantan Timur \\
\hline 6 & Sumatera Selatan & 23 & Sulawesi Utara \\
\hline 7 & Bengkulu & 24 & Sulawesi Tengah \\
\hline 8 & Lampung & 25 & Sulawesi Selatan \\
\hline 9 & Kepulauan Bangka Belitung & 26 & Sulawesi Tenggara \\
\hline 10 & Kepulauan Riau & 27 & Gorontalo \\
\hline 11 & DKI Jakarta & 28 & Maluku \\
\hline 12 & Jawa Barat & 29 & Maluku Utara \\
\hline 13 & Jawa Tengah & 30 & Papua \\
\hline 14 & D I Yogyakarta & & \\
\hline 15 & Jawa Timur & & \\
\hline 16 & Banten & & \\
\hline 17 & Bali & & \\
\cline { 1 - 1 } Sumber: Data diolah, 2018 & & \\
\cline { 1 - 1 } & & \\
\hline
\end{tabular}

\subsection{Operasional Variabel}

Menurut (Sugiyono, 2016), operasional variabel adalah suatu hal yang berbentuk apa saja yang ditetapkan oleh peneliti untuk dipelajari sehingga diperoleh informasi tentang hal tersebut, kemudian ditarik kesimpulannya. Operasional variabel yang digunakan dalam penelitian ini adalah tingkat korupsi sebagai variabel dependen, sedangkan temuan audit, tindak lanjut hasil rekomendasi dan opini audit sebagai variabel independen serta ukuran pemerintah, belanja modal dan indeks pembangunan manusia sebagai variabel kontrol. Berikut tabel operasional variabel:

Tabel 4

Operasional Variabel

\begin{tabular}{|c|c|c|c|}
\hline Variabel & Definisi & Indikator & Skala Ukur \\
\hline $\begin{array}{l}\text { Variabel Independen: } \\
\text { 1. Temuan Audit }\end{array}$ & $\begin{array}{l}\text { Temuan audit adalah hasil } \\
\text { pemeriksaan Badan Pemeriksa } \\
\text { Keuangan (BPK) yang } \\
\text { menunjukkan temuan audit baik } \\
\text { temuan atas pengendalian } \\
\text { internal maupun temuan } \\
\text { ketidakpatuhan atas perundang- } \\
\text { undangan. }\end{array}$ & $\begin{array}{l}\text { Jumlah temuan } \\
\text { pemeriksaan BPK RI } \\
\text { atas pengendalian } \\
\text { internal yang } \\
\text { disesuaikan dengan } \\
\text { jumlah populasi } \\
\text { (temuan } \\
\text { perkapita) }\end{array}$ & Rasio \\
\hline $\begin{array}{ll}\text { 2. } & \text { Tindak Lanjut } \\
& \text { Rekomendasi }\end{array}$ & $\begin{array}{l}\text { Tindak lanjut adalah upaya } \\
\text { untuk melakukan pembetulan } \\
\text { audit berdasarkan masukan dari } \\
\text { auditor BPK agar pihak } \\
\text { pengambil keputusan dapat } \\
\text { menghentikan dan mencegah } \\
\text { terulangnya kembali kesalahan, }\end{array}$ & $\begin{array}{l}\text { Logaritma natural } \\
\text { dari jumlah aset yang } \\
\text { telah dikembalikan ke } \\
\text { kas negara oleh BPK }\end{array}$ & Nominal \\
\hline
\end{tabular}




\begin{tabular}{|c|c|c|c|}
\hline Variabel & Definisi & Indikator & Skala Ukur \\
\hline & $\begin{array}{l}\text { penyimpangan, penyelewengan, } \\
\text { serta pemborosan. }\end{array}$ & & \\
\hline 3. Opini Audit & $\begin{array}{l}\text { Opini audit adalah tingkat } \\
\text { kewajaran yang mencerminkan } \\
\text { tingkat akuntabilitas laporan } \\
\text { keuangan yang diyakini } \\
\text { memberikan kontribusi dalam } \\
\text { usaha mereduksi adanya korupsi. }\end{array}$ & $\begin{array}{l}\text { WTP }=1 \\
\text { Non WTP }=0\end{array}$ & Ordinal \\
\hline $\begin{array}{ll}\text { Variabel Kontrol: } \\
\text { 4. } & \text { Ukuran } \\
& \text { Pemerintah }\end{array}$ & $\begin{array}{l}\text { Dalam konteks pemerintahan, } \\
\text { ukuran menunjukkan seberapa } \\
\text { besar pemerintah daerah tersebut } \\
\text { (Verawaty, 2016). }\end{array}$ & $\begin{array}{l}\text { Logaritma natural } \\
\text { dari total pendapatan }\end{array}$ & Nominal \\
\hline 5. Belanja Modal & $\begin{array}{l}\text { Menurut PP No. } 71 \text { Tahun } 2010 \\
\text { (Republik Indonesia, 2010), } \\
\text { belanja modal adalah } \\
\text { pengeluaran anggaran untuk } \\
\text { perolehan aset tetap dan aset } \\
\text { lainnya yang memberi manfaat } \\
\text { lebih dari satu periode akuntansi. } \\
\text { Belanja modal dilakukan oleh } \\
\text { pemerintah daerah untuk } \\
\text { investasi penambahan dan } \\
\text { pemeliharaan aset tetap sebagai } \\
\text { upaya untuk meningkatkan } \\
\text { pelayanan masyarakat. }\end{array}$ & $\begin{array}{l}\text { Logaritma natural } \\
\text { dari angka belanja } \\
\text { modal }\end{array}$ & Nominal \\
\hline $\begin{array}{ll}6 . & \text { Indeks } \\
& \text { Pembangunan } \\
& \text { Manusia (IPM) }\end{array}$ & $\begin{array}{l}\text { IPM adalah indikator } \\
\text { kesejahteraan masyarakat untuk } \\
\text { menghasilkan suatu ukuran yang } \\
\text { merefleksikan upaya } \\
\text { pembangunan manusia. }\end{array}$ & $\begin{array}{l}\text { Rata-rata lama } \\
\text { sekolah (MYS) }\end{array}$ & Nominal \\
\hline $\begin{array}{l}\text { Variabel Dependen: } \\
\text { 7. Tingkat Korupsi }\end{array}$ & $\begin{array}{l}\text { Tingkat korupsi adalah } \\
\text { perbuatan melawan hukum yang } \\
\text { merugikan atau dapat merugikan } \\
\text { keuangan negara atau } \\
\text { perekonomian negara serta } \\
\text { merugikan kesejahteraan atau } \\
\text { kepentingan rakyat/umum. }\end{array}$ & $\begin{array}{l}\text { Tindak pidana } \\
\text { korupsi yang } \\
\text { ditangani oleh } \\
\text { Kejaksaan Tinggi } \\
\text { dibagi dengan } 10.000 \\
\text { penduduk }\end{array}$ & Rasio \\
\hline
\end{tabular}

Sumber: Data diolah, 2018

\subsection{Analisis Regresi Berganda}

Analisis regresi berganda (multivariative regression) merupakan suatu model dimana variabel terikat tergantung pada dua atau lebih variabel bebas. Analisis ini digunakan untuk mengetahui bagaimana satu variabel yaitu variabel dependen dipengaruhi oleh satu atau lebih dari variabel lain yaitu variabel independen dengan tujuan untuk mengestimasi atau memprediksi nilai rata-rata variabel dependen yang berdasarkan pada nilai variabel independen yang yang dpilih untuk diteliti. Dengan demikian, tujuan utama analisis regresi ini adalah untuk memprediksi nilai variabel dependen berdasarkan satu atau lebih variabel independen. Persamaan regresi yang digunakan dalam penelitian ini adalah:

KRP $=a+\beta_{2}$ TMA $+\beta_{3}$ TLRHP $+\beta_{4}$ OPI $+\beta_{5}$ REV + $\beta_{6}$ BMOD $+\beta_{6}$ IPM +e 
Keterangan:

KRP : Jumlah kasus tindak pidana korupsi

a : Konstanta

TMA : Temuan Audit BPK

TLRHP : Tindak lanjut rekomendasi hasil pemeriksaan

OPI : Opini Audit

REV : Ukuran Pemerintah

BMOD : Belanja Modal

IPM : Indeks Pembangunan Manusia

$\beta 1-\beta 6$ : Koefisien regresi tiap variabel independen

e : Faktor pengganggu/kesalahan (error)

Adapun uji hipotesis yang dilakukan adalah uji koefisien determinasi (R2), Uji T (uji parsial) dan Uji F (uji simultan).

\section{Hasil dan Pembahasan}

4.1 Statistik Deskriptif

Berikut ini tabel statistik deskriptif untuk masing-masing variabel penelitian.

Tabel 5

Statistik Deskriptif Variabel

\begin{tabular}{|l|l|l|l|l|l|}
\hline & N & Minimum & Maximum & Mean & $\begin{array}{l}\text { Std. } \\
\text { Deviation }\end{array}$ \\
\hline Temuan Audit BPK & 30 & 25 & 228 & 53.33 & 36.349 \\
\hline Tindak Lanjut Rekomendasi & 30 & 17.70 & 25.13 & 21.8233 & 1.68134 \\
\hline Opini Audit & 30 & .00 & 1.00 & .8333 & .37905 \\
\hline Ukuran Pemerintah & 30 & 21.42 & 31.42 & 28.9734 & 1.66514 \\
\hline Belanja Modal & 30 & 25.53 & 29.96 & 27.5074 & .90473 \\
\hline Indeks Pembangunan Manusia & 30 & 5.99 & 10.70 & 8.0793 & .98357 \\
\hline Tingkat Korupsi & 30 & .00180 & .01290 & .0048700 & .00291289 \\
\hline Valid N (listwise) & 30 & \multicolumn{3}{|l}{} & \\
\hline
\end{tabular}

Sumber: Data diolah, 2018

Berdasarkan tabel 5 statistik deskriptif variabel penelitian, terlihat bahwa dari 30 provinsi yang menjadi sampel penelitian, variabel tingkat korupsi memiliki rata-rata (mean) jumlah tingkat korupsi sebesar 0,0487 dengan standar deviasi 0,029 dimana nilai standar deviasi lebih kecil dibandingkan nilai rata-rata tingkat korupsi. Demikian pula nilai minimum sebesar 0,0018 lebih kecil dibanding nilai rata-ratanya, berbeda dengan nilai maksimum sebesar 0,129 yang lebih besar dari nilai rata-ratanya.

Jumlah temuan audit oleh BPK mempunyai nilai rata-rata (mean) sebesar 53,33 dengan standar deviasi sebesar 36,349. Demikian pula dengan nilai minimum sebesar 25 temuan dan nilai maksimum 228 temuan.

Tindak lanjut rekomendasi rata-rata nilai penyetoran atau penyerahan aset ke kas negara/daerah/perusahaan sebagai bentuk dari tindak lanjut rekomendasi atas temuan audit yaitu 21,82. dimana nilai standar deviasi lebih besar daripada nilai 1,68. Demikian 
pula dengan nilai minimum sebesar 17,69 lebih kecil dari nilai rata-ratanya, berbeda dengan nilai maksimum sebesar 25,13 yang lebih besar daripada nilai rata-ratanya.

Ukuran pemerintah mempunyai rata-rata untuk provinsi yang menjadi sampel adalah 28,97. Standar deviasi variabel ukuran pemerintah provinsi adalah 1,66. Demikian pula dengan nilai minimum sebesar 21,41 lebih kecil dari nilai rata-ratanya, berbeda dengan nilai maksimum sebesar 31,41 yang lebih besar daripada nilai rata-ratanya.

Belanja modal mempunyai nilai rata-rata untuk provinsi yang menjadi sampel adalah 27,50 Standar deviasi variabel belanja modal adalah 0,90. Demikian pula dengan nilai minimum sebesar 21,41 lebih kecil dari nilai rata-ratanya, berbeda dengan nilai maksimum sebesar 29,95 yang lebih besar daripada nilai rata-ratanya.

Indeks pembangunan manusia mempunyai nilai rata-rata (mean) sebesar 8,07 dengan standar deviasi 0,98 dimana nilai standar deviasi lebih kecil daripada nilai rata-ratanya. Demikian pula dengan nilai minimum sebesar 5,99 yang lebih kecil dari daripada nilai rata-ratanya, berbeda dengan nilai maksimum sebesar 10,70 yang lebih besar daripada nilai rata-ratanya.

Variabel opini audit yang menggunakan variabel dummy pengujiannya dilakukan secara terpisah dengan menggunakan analisis frekuensi. Berikut hasil pengujian analisis frekuensi yang telah dilakukan:

Tabel 6

Hasil Analisis Frekuensi Opini Audit

\begin{tabular}{|l|l|l|l|l|l|}
\hline \multicolumn{2}{|c|}{} & Frequency & Percent & Valid Percent & Cumulative Percent \\
\hline Valid & NON WTP & 5 & 16.7 & 16.7 & 16.7 \\
& WTP & 25 & 83.3 & 83.3 & 100.0 \\
& Total & 30 & 100.0 & 100.0 & \\
\hline
\end{tabular}

Sumber: Data diolah, 2018

Berdasarkan tabel 6 di atas, hasil analisis frekuensi opini audit (OA), menunjukkan bahwa pemerintah daerah pada tahun 2015 yang memperoleh opini wajar tanpa pengecualian sebanyak 25 provinsi dengan persentase $83,3 \%$ dan provinsi yang memperoleh opini wajar tanpa pengecualian dengan pembahasan sebanyak 5 provinsi dengan persentase $16,7 \%$.

\subsection{Uji Koefisien Determinasi $\left(R^{2}\right)$}

Koefisien Determinasi $\left(\mathrm{R}^{2}\right)$ bertujuan untuk menilai seberapa besar kemampuan model penelitian dalam menerangkan variasi pada variabel dependen. Nilai koefisien determinasi adalah antara nol dan satu. Berikut ini tabel hasil uji koefisien determinasi: 
Tabel 7

Hasil Uji Koefisien Determinasi $\left(\mathrm{R}^{2}\right)$

\begin{tabular}{|l|l|l|l|l|l|}
\hline \multicolumn{5}{|c|}{ Model Summary $^{\mathbf{b}}$} \\
\hline Model & $\mathbf{R}$ & R Square & Adjusted R Square & $\begin{array}{l}\text { Std. Error of the } \\
\text { Estimate }\end{array}$ \\
\hline 1 & $.690^{\mathrm{a}}$ & .475 & .339 & .00236899 \\
\hline $\begin{array}{l}\text { a. Predictors: (Constant), Indeks Pembangunan Manusia, Ukuran Pemerintah, LN_X2, Opini Audit, } \\
\text { Temuan Audit BPK, Belanja Modal }\end{array}$ \\
b. Dependent Variable: Tingkat Korupsi \\
Sumber: Data diolah, 2018
\end{tabular}

Berdasarkan tabel hasil uji $\mathrm{R}^{2}$ tersebut, model summary besarnya koefisien determinasi ditunjukkan pada nilai adjusted $\mathrm{R}^{2}$ yaitu sebesar 0,339 . Hal ini berarti bahwa 33,9\% variabel tingkat korupsi dapat dijelaskan oleh variabel temuan audit, tindak lanjut hasil rekomendasi, opini audit, ukuran pemerintah, belanja modal, indeks pembangunan manusia, sedangkan sisanya $66,1 \%$ variabel dependen dijelaskan oleh variabel lain yang tidak diteliti dalam penelitian ini atau faktor-faktor lain di luar model penelitian.

\subsection{Uji Signifikansi Simultan (Uji F)}

Uji statistik F digunakan untuk mengetahui apakah model regresi layak digunakan dalam penelitian (Ghozali, 2013). Uji statistik F pada dasarnya menunjukkan apakah semua variabel bebas dalam model mempunyai pengaruh secara simultan terhadap variabel dependen. Berikut ini tabel hasil uji signifikansi simultan:

Tabel 8

Hasil Uji Signifikansi Simultan (Uji F)

\begin{tabular}{|c|c|c|c|c|c|c|}
\hline \multicolumn{7}{|c|}{ ANOVA $^{a}$} \\
\hline \multicolumn{2}{|c|}{ Model } & $\begin{array}{l}\text { Sum of the } \\
\text { Squares }\end{array}$ & Df & Mean Square & $\mathbf{F}$ & Sig. \\
\hline \multirow[t]{3}{*}{1} & Regression & .000 & 6 & .000 & 3.474 & $.014^{\mathrm{b}}$ \\
\hline & Residual & .000 & 23 & .000 & & \\
\hline & Total & .000 & 29 & & & \\
\hline \multicolumn{7}{|c|}{ a. Dependent Variable: Tingkat Korupsi } \\
\hline \multicolumn{7}{|c|}{$\begin{array}{l}\text { b. Predictors: (Constant), Indeks Pembangunan Manusia, Ukuran Pemerintah, LN_X2, Opini Audit, } \\
\text { Temuan Audit BPK, Belanja Modal }\end{array}$} \\
\hline
\end{tabular}

Berdasarkan hasil uji ANOVA atau F di atas, didapat $\mathrm{F}$ hitung sebesar 3,47 dengan tingkat korupsi 0,014 (signifikan). Tabel 8 yaitu hasil uji $\mathrm{F}$ (regresi simultan) menunjukkan bahwa nilai signifikan lebih kecil dari tingkat signifikansi 0,05 , jadi dapat disimpulkan bahwa temuan audit, tidak lanjut rekomendasi, opini audit, ukuran pemerintah, belanja modal, indeks pembangunan manusia berpengaruh terhadap tingkat korupsi.

\subsection{Uji Signifikansi Parsial (Uji t)}

Uji statistik t digunakan untuk menunjukkan seberapa jauh pengaruh satu variabel penjelas (independen) secara individual dalam menerangkan variasi variabel dependen (Ghozali, 2013). Untuk mengetahui pengaruh tersebut maka digunakan tingkat 
signifikansi sebesar 5\%. Dari pengujian hipotesis secara parsial diperoleh hasil yaitu sebagai berikut:

Tabel 9

Hasil Uji Signifikansi Simultan Parsial (Uji t)

\begin{tabular}{|c|c|c|c|c|c|c|}
\hline \multicolumn{7}{|c|}{ Coefficients $^{\mathrm{a}}$} \\
\hline & & \multicolumn{2}{|c|}{$\begin{array}{l}\text { Unstandardized } \\
\text { Coefficients }\end{array}$} & \multirow{2}{*}{\begin{tabular}{|l|}
$\begin{array}{l}\text { Standardized } \\
\text { Coefficients }\end{array}$ \\
Beta \\
\end{tabular}} & \multirow[b]{2}{*}{$\mathbf{T}$} & \multirow[b]{2}{*}{ Sig. } \\
\hline & & B & $\begin{array}{l}\text { Std. } \\
\text { Error }\end{array}$ & & & \\
\hline \multirow[t]{7}{*}{1} & (Constant) & -.035 & .017 & & -2.022 & .055 \\
\hline & Temuan Audit BPK & $2.002 \mathrm{E}-5$ & .000 & .250 & 1.147 & .263 \\
\hline & Tindak Lanjut Rekomendasi & .001 & .000 & .377 & 2.102 & .047 \\
\hline & Opini Audit & .002 & .001 & 207 & 1.253 & .223 \\
\hline & Ukuran Pemerintah & .000 & .000 & .243 & 1.401 & .175 \\
\hline & Belanja Modal & .001 & .001 & .163 & .727 & .475 \\
\hline & $\begin{array}{l}\text { Indeks Pembangunan } \\
\text { Manusia }\end{array}$ & .000 & .001 & -.156 & -.907 & .374 \\
\hline
\end{tabular}

Sumber: Data diolah, 2018

Berdasarkan hasil uji statistik pada tabel 9, variabel temuan audit (TMA) memiliki koefisien regresi sebesar 0,000020. Nilai $t$ hitung sebesar 1,147 dengan tingkat signifikansi 0,263. Karena tingkat signifikansi di atas 0,05, maka dapat disimpulkan bahwa temuan audit tidak berpengaruh terhadap tingkat korupsi.

Hasil uji t untuk variabel tindak lanjut hasil audit (TLRHP) menunjukkan nilai koefisien regresi sebesar 0,001. Nilai koefisien regresi yang negatif menunjukkan tindak lanjut hasil audit berpengaruh negatif terhadap tingkat korupsi provinsi. Nilai t hitung sebesar 2,102 dengan tingkat signifikansi sebesar 0,047. Hal tersebut menunjukkan tingkat signifikansi di bawah 0,05, sehingga dapat disimpulkan tindak lanjut hasil rekomendasi audit berpengaruh terhadap tingkat korupsi.

Opini audit memiliki koefisien regresi sebesar 0,002. Nilai t hitung sebesar 1,253 dengan tingkat signifikansi 0,223 . Karena tingkat signifikansi di atas 0,05 , maka dapat disimpulkan bahwa opini audit tidak berpengaruh terhadap tingkat korupsi.

Ukuran pemerintah memiliki koefisien regresi sebesar 0,000. Nilai t hitung sebesar 1,401 dengan tingkat signifikansi 0,175. Karena tingkat signifikansi di atas 0,05, maka dapat disimpulkan bahwa ukuran pemerintah tidak berpengaruh terhadap tingkat korupsi.

Belanja modal memiliki koefisien regresi sebesar 0,001. Nilai t hitung sebesar 0,727 dengan tingkat signifikansi 0,475 . Karena tingkat signifikansi di atas 0,05, maka dapat disimpulkan bahwa belanja modal tidak berpengaruh terhadap tingkat korupsi.

Hasil uji t untuk variabel indeks pembangunan manusia menunjukkan nilai koefisien regresi sebesar 0,000. Nilai koefisien regresi yang negatif menunjukkan indeks pembangunan manusia berpengaruh negatif terhadap tingkat korupsi provinsi. Nilai $\mathrm{t}$ hitung sebesar -0,907 dengan tingkat signifikansi sebesar 0,374. Hal tersebut 
menunjukkan tingkat signifikansi di bawah 0,05, sehingga dapat disimpulkan indeks pembangunan manusia tidak berpengaruh terhadap tingkat korupsi.

Setelah melakukan analisis regresi berganda dari tabel 9 di atas, maka nilai-nilai koefisien regresi tersebut dapat dimasukkan ke dalam persamaan regresi yang disusun dalam persamaan regresi linier berganda sebagai berikut:

$$
\begin{gathered}
\mathrm{TK}=-0,035+0,000020 \mathrm{TMA}+0,001 \mathrm{TRLHP}+0,002 \mathrm{OPI}+0,000 \mathrm{REV}+0,001 \\
\text { BMOD + 0.000 IPM + e }
\end{gathered}
$$

Persamaan tersebut dapat menunjukkan jika seluruh variabel bebas yaitu temuan audit, tindak lanjut rekomendasi, opini audit, ukuran pemerintah, belanja modal, indeks pembangunan manusia bernilai 1 , maka aksesibilitas nilainya negatif $-0,035$. Variabel temuan audit memiliki koefisien yang positif yaitu 0,000020. Hal ini menunjukkan bahwa setiap peningkatan temuan audit sebesar 1, maka tingkat korupsi akan meningkat sebesar 0,000020 dengan asumsi bahwa variabel independen lainnya tetap. Variabel tindak lanjut rekomendasi memiliki koefisien yang positif yaitu 0,263 . Hal ini menunjukkan bahwa setiap peningkatan sebesar 1, maka tingkat korupsi akan meningkat sebesar 0,263 dengan asumsi bahwa variabel independen lainnya tetap. Variabel opini audit memiliki koefisien yang positif yaitu 0,002 . Hal ini menunjukkan bahwa setiap peningkatan opini audit sebesar 1, maka tingkat korupsi akan meningkat sebesar 0,002 dengan asumsi bahwa variabel independen lainnya tetap. Variabel ukuran pemerintah memiliki koefisien yang positif yaitu 0,000 . Hal ini menunjukkan bahwa setiap peningkatan ukuran pemerintah sebesar 1, maka tingkat korupsi akan meningkat sebesar 0,000 dengan asumsi bahwa variabel independen lainnya tetap. Variabel belanja modal memiliki koefisien yang positif yaitu 0,001 . Hal ini menunjukkan bahwa setiap peningkatan belanja modal sebesar 1, maka tingkat korupsi akan meningkat sebesar 0,001 dengan asumsi bahwa variabel independen lainnya tetap. Variabel indeks pembangunan manusia memiliki koefisien yang negatif yaitu 0,000. Hal ini menunjukkan bahwa setiap peningkatan indeks pembangunan manusia sebesar 1, maka tingkat korupsi akan menurun sebesar 0,000 dengan asumsi bahwa variabel independen lainnya tetap.

Untuk menguji signifikansi dari setiap variabel bebas yang digunakan p-value (probability value) dengan tingkat signifikansi sebesar 5\% (0,05). Apabila nilai signifikansi lebih kecil dari 0,05 maka koefisien regresi adalah signifikan. Dari hasil pengujian hipotesis secara parsial di atas, maka dapat dianalisis sebagai berikut:

1. Variabel Temuan Audit (TMA)

Berdasarkan hasil pengolahan data, diperoleh nilai signifikansi 0,263 > level of signifikan $(\alpha)=0,05$. Karena nilai signifikansi lebih besar dari 0,5 , maka dapat disimpulkan bahwa tidak terdapat pengaruh signifikan antara temuan audit terhadap tingkat korupsi.

2. Variabel Tindak Lanjut Rekomendasi (TRLHP)

Berdasarkan hasil pengolahan data, diperoleh nilai signifikansi 0,047 < level of signifikan $(\alpha)=0,05$. Karena nilai signifikansi lebih kecil dari 0,05, maka dapat disimpulkan bahwa terdapat pengaruh signifikan antara tindak lanjut rekomendasi terhadap tingkat korupsi. 
3. Variabel Opini Audit (OPI)

Berdasarkan hasil pengolahan data, diperoleh nilai signifikansi 0,223 > level of signifikan $(\alpha)=0,05$. Karena nilai signifikansi lebih besar dari 0,05, maka dapat disimpulkan bahwa tidak terdapat pengaruh signifikan antara opini audit terhadap tingkat korupsi.

4. Variabel Ukuran Pemerintah

Berdasarkan hasil pengolahan data, diperoleh nilai signifikansi 0,175> level of signifikan $(\alpha)=0,05$. Karena nilai signifikansi lebih besar dari 0,05, maka dapat disimpulkan bahwa tidak terdapat pengaruh signifikan antara ukuran pemerintah terhadap tingkat korupsi.

5. Berdasarkan hasil pengolahan data, diperoleh nilai signifikansi $0,475>$ level of signifikan $(\alpha)=0,05$. Karena nilai signifikansi lebih besar dari 0,05 , maka dapat disimpulkan bahwa tidak terdapat pengaruh signifikan antara belanja modal terhadap tingkat korupsi.

6. Berdasarkan hasil pengolahan data, diperoleh nilai signifikansi 0,374> level of signifikan $(\alpha)=0,05$. Karena nilai signifikansi lebih besar dari 0,05 , maka dapat disimpulkan bahwa tidak terdapat pengaruh antara indeks pembangunan manusia terhadap tingkat korupsi.

\subsection{Pembahasan}

\subsubsection{Pengaruh Temuan Audit terhadap Tingkat Korupsi}

Hasil pengujian hipotesis pertama menunjukkan bahwa temuan audit atas kelemahan sistem pengendalian intern berpengaruh positif terhadap tingkat korupsi pemerintah daerah, ditolak. Hasil pengujian menunjukkan bahwa temuan audit berpengaruh positif terhadap tingkat korupsi dengan nilai signifikansi 0,263 yang dimana nilai tersebut lebih besar dari 0,05 $(\alpha=5 \%)$ dan nilai beta sebesar 0,000020. Maka dari itu, berdasarkan hasil hipotesis tersebut menyatakan bahwa temuan audit tidak dapat mempengaruhi tingkat korupsi.

Temuan audit merupakan hasil pemeriksaan Badan Pemeriksa Keuangan (BPK) yang menunjukkan temuan audit baik temuan atas pengendalian internal maupun temuan ketidakpatuhan atas perundang-undangan. Cara yang utama untuk mencegah terjadinya kecurangan yaitu dengan adanya sistem pengendalian internal yang kuat. Hasil penelitian tidak konsisten dengan hasil (Liu \& Lin, 2012) yang menyatakan bahwa temuan audit berpengaruh positif terhadap tingkat korupsi provinsi di China. Selain itu (Huefner, 2011) yang menyatakan bahwa temuan audit atas sistem pengendalian internal dapat digunakan untuk mendeteksi adanya potensi kecurangan di pemerintah daerah yang ada di Indonesia.

Akan tetapi hasil penelitian ini konsisten dengan hasil penelitian sebelumnya yang dilakukan (Masyitoh et al., 2015) dan (Lukfiarini, 2018) yang membuktikan bahwa temuan audit atas kelemahan sistem pengendalian internal tidak berpengaruh terhadap persepsi korupsi di pemerintah daerah. Temuan audit tidak berpengaruh terhadap tingkat korupsi pemerintah provinsi. Hal ini dikarenakan dalam penelitian ini temuan audit termasuk temuan atas kelemahan sistem pengendalian internal yang bukan merupakan suatu pelanggaran dan tidak menimbulkan kerugian berupa materiil dalam keuangan pemerintah daerah. Menurut (Masyitoh et al., 2015), korupsi terjadi pada temuan pelanggaran yang mengakibatkan kerugian dalam keuangan daerah baik yang terjadi 
secara nyata maupun yang masih bersifat potensi sehingga hanya membutuhkan perbaikan dalam tatanan sistem pengendalian dan pelaksanaannya secara optimal.

\subsubsection{Pengaruh Tindak Lanjut Rekomendasi terhadap Tingkat Korupsi}

Hasil pengujian hipotesis kedua menunjukkan bahwa tindak lanjut hasil audit yang dilaksanakan oleh pemerintah daerah berpengaruh negatif terhadap tingkat korupsi, diterima. Hasil pengujian menunjukkan bahwa tindak lanjut rekomendasi berpengaruh terhadap tingkat korupsi dengan nilai signifikansi 0,046 dan nilai tersebut lebih kecil dari $0,05(\alpha=5 \%)$. Maka dari itu, berdasarkan hasil hipotesis tersebut menyatakan bahwa tindak lanjut rekomendasi dapat mempengaruhi tingkat korupsi pemerintah daerah. Dalam hal ini semakin banyaknya tindak lanjut audit yang dilihat dari nilai perkapita yang diserahkan ke kas negara menyebabkan menurunnya tingkat korupsi.

Undang-Undang Nomor 15 tahun 2004 (Republik Indonesia, 2004)menyatakan secara tegas bahwa pejabat wajib menindaklanjuti rekomendasi dalam Laporan Hasil Pemeriksaan dan wajib memberikan jawaban atau penjelasan kepada BPK tentang tindak lanjut atas rekomendasi tersebut. Tindak lanjut rekomendasi hasil pemeriksaan adalah kegiatan dan atau keputusan yang dilakukan oleh pejabat yang diperiksa dan/atau pihak lain yang kompeten untuk melaksanakan rekomendasi hasil pemeriksaan BPK.

Penelitian ini konsisten dengan hasil (Liu \& Lin, 2012) bahwa pembetulan setelah adanya proses audit lebih penting dari deteksi atas temuan audit itu sendiri karena upaya untuk melakukan pembetulan audit dapat meningkatkan efektivitas proses audit. Hasil penelitian ini mendukung (Liu \& Lin, 2012), (Azhar \& Setyaningrum, 2015), (Masyitoh et al., 2015), (Yuliyana \& Setyaningrum, 2016) serta (Lukfiarini, 2018) yang menyatakan bahwa terdapat pengaruh positif antara ukuran pemerintahan dengan tingkat korupsi. Semakin besar ukuran pemerintah provinsi yang dilihat dari proporsi belanja terhadap PDRB, akan meningkatkan korupsi di provinsi tersebut. Hal ini disebabkan banyaknya belanja yang dilakukan, potensi penyimpangan ataupun penyelewengan akan semakin besar yang mengakibatkan tingkat korupsi meningkat.

Hal serupa dikemukakan oleh (Umar, 2012) bahwa dengan adanya masukan dari auditor, pihak pengambil keputusan dapat menghentikan dan mencegah terulangnya kembali kesalahan, penyimpangan, penyelewengan, serta pemborosan. Dengan demikian semakin melaksanakan apa yang telah direkomendasikan oleh auditor, maka pemerintah semakin memperbaiki kesalahan dalam pertanggungjawaban penyelenggaraan negara sehingga dapat mencegah terjadinya kesalahan penyimpangan, penyelewengan dan pemborosan.

\subsubsection{Pengaruh Opini Audit terhadap Tingkat Korupsi}

Hasil pengujian hipotesis ketiga menunjukkan bahwa opini audit berpengaruh negatif terhadap tingkat korupsi, ditolak. Hasil pengujian menunjukkan bahwa opini audit tidak berpengaruh terhadap tingkat korupsi dengan nilai signifikansi 0,222 yang dimana nilai tersebut lebih besar dari 0,05 $(\alpha=5 \%)$. Maka dari itu, berdasarkan hasil hipotesis tersebut menyatakan bahwa opini audit tidak dapat mempengaruhi tingkat korupsi pemerintah daerah di Indonesia. 
Opini atas audit yang diberikan kepada suatu provinsi tidak memiliki pengaruh terhadap tingkat korupsi di provinsi tersebut, sehingga hipotesis ketiga tidak berhasil didukung. Hasil penelitian ini tidak mendukung hasil penelitian sebelumnya yang dilakukan (Masyitoh et al., 2015) yang menyatakan opini audit berpengaruh terhadap persepsi korupsi pemerintah daerah serta (Rini \& Sarah, 2014) dan (Ismunawan, 2016) yang menyatakan terdapat kaitan antara opini audit dengan tingkat korupsi di pemerintah daerah.

Hasil penelitian ini mendukung hasil penelitian sebelumnya yang dilakukan oleh (Heriningsih \& Marita, 2013) dan (Lukfiarini, 2018) yang menyatakan bahwa opini audit tidak memiliki pengaruh terhadap tingkat korupsi di pemerintah daerah. Pemerintah provinsi yang mendapatkan opini Wajar Tanpa Pengecualian (WTP) ataupun disclaimer tetap terindikasi melakukan tindak pidana korupsi. Jadi, walaupun opini audit bagus masih terdapat kemungkinan terjadinya korupsi. (Effendy, 2013) menyatakan bahwa opini WTP dari Badan Pemeriksa Keuangan (BPK) tidak mempengaruhi kasus korupsi yang terjadi pada pemerintah daerah di Indonesia. (Effendy, 2013) juga menyatakan bahwa opini WTP tidak dapat menjamin baik-buruknya pengelolaan keuangan. Banyaknya temuan kasus korupsi menunjukkan masih tingginya kasus keuangan di Indonesia khususnya pemerintah daerah, perilaku dan kedudukan BPK, masyarakat dan pihak pemerintah yang kurang tegas dan disiplin sehingga terjadi korupsi. Opini audit yang baik tidak menjadi jaminan bebasnya suatu pemerintah provinsi dari korupsi. Hal ini disebabkan opini audit yang diberikan oleh BPK hanya menilai tata kelola keuangan yang dilakukan pemerintah provinsi adalah baik dan penyajian laporan keuangannya wajar.

\subsubsection{Pengaruh Ukuran Pemerintah terhadap Tingkat Korupsi}

Hasil pengujian menunjukkan bahwa ukuran pemerintah sebagai variabel kontrol tidak berpengaruh terhadap tingkat korupsi dengan nilai signifikansi 0,174 yang dimana nilai tersebut lebih besar dari 0,05 $(\alpha=5 \%)$. Hasil penelitian ini tidak mendukung (Liu \& Lin, 2012) yang menyatakan bahwa terdapat pengaruh positif antara ukuran pemerintahan dengan tingkat korupsi serta (Lessmann \& Markwardt, 2010), ukuran pemerintahan berpengaruh negatif terhadap persepsi korupsi. (Sumarjo, 2010) mengasumsikan bahwa tuntutan terhadap pemerintah yang mempunyai ukuran lebih besar akan lebih tinggi dari pada pemerintah yang mempunyai ukuran kecil. Hal ini akan memberikan dampak pada kinerja keuangannya. Semakin besar ukuran pemerintah daerah maka akan semakin besar pula sumber daya yang dimiliki untuk memberikan pelayanan kepada masyarakat yang tentunya diharapkan akan dapat meningkatkan kinerja pemerintah daerah tersebut.

(Verawaty, 2017) menyatakan ukuran adalah indikator nominal yang dapat mendeskripsikan seberapa besar suatu pemerintah tersebut. Dalam konteks pemerintahan, besar kecilnya ukuran suatu pemerintahan dapat dilihat dari total pendapatan yang diperoleh daerah dalam setahun (Kristanto, 2009). Semakin besar ukuran organisasi, maka tuntutan untuk pertanggungjawaban dan kinerja juga semakin besar. Tantangan dalam optimalisasi ukuran pemerintah daerah adalah; 1) kapasitas, ukuran pemerintah berperan dalam kecukupan keuangan atau kapasitas manajerial, dan 2) fragmentasi dapat melemahkan efisiensi sehingga menghalangi perlunya koordinasi untuk persaingan dalam ekonomi regional (Warmer, 2012). Namun hasil penelitian ini tidak mendukung 
hal tersebut karena ukuran pemerintah yang kecil pun, tekanan terhadap pengendalian keuangan daerahnya juga tepat tegas atau hal lainnya adalah ukuran pemerintah yang besar yang disinyalir akan lebih terpantau malah memiliki tingkat korupsi yang cukup tinggi.

\subsubsection{Pengaruh Belanja Modal terhadap Tingkat Korupsi}

Hasil pengujian menunjukkan bahwa belanja modal sebagai variabel kontrol tidak berpengaruh terhadap tingkat korupsi dengan nilai signifikansi 0,474 yang dimana nilai tersebut lebih besar dari $0,05(\alpha=5 \%)$. Belanja modal adalah pengeluaran pemerintah daerah yang digunakan untuk penyediaan dan perawatan infrastruktur dan sarana prasarana. Menurut (Harianto \& Adi, 2007), infrastruktur dan sarana prasarana yang memadai di daerah akan berdampak pada pertumbuhan ekonomi daerah yang ditandai dengan produktivitas masyarakat yang meningkat dan bertambahnya investor. Peningkatan belanja modal oleh pemerintah daerah diharapkan mampu meningkatkan kualitas pelayanan publik dan selanjutnya meningkatkan partisipasi masyarakat terhadap pembangunan yang tercermin dari peningkatan pendapatan asli daerah (Mardiasmo, 2009). Hasil penelitian ini tidak konsisten dengan hasil (Windarti, 2015) dan (Ismunawan, 2016) yang menemukan hubungan bahwa tingkat korupsi yang tinggi bisa dikaitkan dengan pengeluaran pemerintah pada bidang infrastruktur publik.

Di Indonesia sendiri, berbagai kasus korupsi dilakukan oleh oknum-oknum yang mempunyai jabatan dan tentu saja penghasilannya sudah besar. Implikasinya, pada lingkungan masyarakat yang korup, kenaikan upah sektor publik hanya akan meningkatkan biaya dan upaya korupsi berikutnya. Pada variabel belanja modal, tingkat korupsi yang semakin tinggi diasosiasikan dengan tingginya investasi publik maka akan semakin rendahnya pendapatan pemerintah, rendahnya pengeluaran pemerintah pada bidang operasi dan pemeliharaan, serta rendahnya kualitas infrastruktur publik. Direktorat Jenderal Perimbangan Keuangan Kementrian Keuangan, Boediarso Teguh Widodo pada tahun 2017 dalam (Detik Finance, 2017) mengatakan pengelolaan anggaran di daerah masih jauh dari efektif dan efisien. Hal ini bisa dilihat dari alokasi belanja pegawai yang jauh lebih besar dari belanja modal. Realisasi belanja modal juga terbilang lambat lantaran simpanan uang pemerintah daerah di perbankan tercatat dari tahun ke tahun semakin meningkat. Fakta yang ada korupsi pejabat di daerah terhadap anggaran yang ada, Kepala Daerah yang terdiri dari Gubernur, Bupati dan Wali Kota yang korupsi. Korupsi terbesar ada pada pelaksanaan dari pengadaan barang untuk konstruksi bangunan. Kenaikan dari belanja APBD dan transfer ternyata tidak diikuti dengan pengelolaan anggaran yang efektif dan efisien. Transformasi pengelolaan keuangan negara merupakan suatu kebutuhan yang mendesak dan krusial. Perlu untuk segera dilakukan transformasi, mengingat pengelolaan APBN dan APBD masih terdapat celah untuk diperbaiki supaya bisa efektif, efisien, optimal dan produktif.

\subsubsection{Pengaruh Indeks Pembangunan Manusia terhadap Tingkat Korupsi}

Hasil pengujian menunjukkan bahwa indeks pembangunan manusia sebagai variabel kontrol tidak berpengaruh terhadap tingkat korupsi dengan nilai signifikansi 0,373 yang dimana nilai tersebut lebih besar dari 0,05 $(\alpha=5 \%)$. Proksi yang digunakan adalah MYS, yaitu gambaran terhadap keterampilan yang dimiliki penduduk. Salah satu yang mempengaruhi korupsi adalah pengetahuan yang diukur berdasarkan rata-rata lama 
sekolah (Franciari \& Sugiyanto, 2013). Variabel indeks pembangunan manusia menunjukkan semakin tinggi pendidikan masyarakat akan meningkatkan kemampuan pengawasan yang dilakukan, sehingga mengurangi kemungkinan terjadinya tindakan menyimpang yang dilakukan oleh aparat pemerintah daerah. Hasil penelitian ini tidak konsisten dengan (Rajasa, 2014) yang menyatakan indeks pembangunan manusia berpengaruh terhadap tingkat korupsi.

Akan tetapi penelitian ini konsisten dengan pernyataan Dendy Susianto selaku salah satu konsultan politik di Indonesia dalam (Republika, 2013) yang menyatakan bahwa semakin tinggi tingkat pendidikan seseorang ternyata tidak berpengaruh terhadap perilaku korupsi ataupun berpendidikan tinggi, orang masih cenderung korupsi. Hal ini merupakan hasil survei independen yang dilakukan Institut Survei Perilaku Politik. Survei digelar pada Oktober 2013 di 33 provinsi di Indonesia. Sebanyak 1.500 orang responden. Sebagai contoh dalam survei sebanyak 19,3 persen responden orang yang berpendidikan tinggi memilih memberi uang 'suap' saat pengurusan KTP. Sementara 16,3 persen orang berpendidikan rendah memperbolehkan pemberian uang lelah kepada pegawai kelurahan dalam pengurusan KTP. Pendidikan tinggi didefinisikan sebagai orang yang mendapat pendidikan SMA ke atas dan berpendidikan rendah untuk orang yang berpendidikan SMP ke bawah. Tingginya tingkat korupsi tidak menjamin orang bersikap lebih anti-korupsi (Dendy Susianto dalam (Republika, 2013). Jumono dari Indonesia Corruption Watch (ICW) dalam (CNN Indonesia, 2016) menyatakan walaupun negara telah mengalokasikan Anggaran Pengeluaran dan Belanja Negara (APBN) untuk sektor pendidikan, berupa sarana dan prasarana pendidikan tidak akan memberi dampak yang signifikan dalam tingkat korupsi. Celah untuk korupsi adalah Dana Alokasi Khusus (DAK) yang menyebabkan kerugian oleh negara. Menurut Jumono dalam (CNN Indonesia, 2016) juga menyatakan bahwa tingginya tingkat korupsi dalam sektor pendidikan membuat rencana dan program-program pemerintah dalam rangka meningkatkan kesejahteraan masyarakat dalam hal pendidikan tidak berjalan maksimal. Sebagai contoh, besarnya jumlah DAK atau Dana Operasional Sekolah (BOS) yang dikorupsi membuat biaya pendidikan semula ditetapkan oleh pemerintah gratis menjadi belum sepenuhnya bebas dari biaya. Faktanya sampai hari ini buku sekolah gratis di pelosok daerah masih belum merata. Dana BOS banyak dikorupsi, padahal ini bias berimbas juga pada kinerja dan kualitas mengajar para guru. Selain itu, sejalan dengan analisis (Kurniawan, 2009) bahwa peranan akuntabilitas publik dan dan partisipasi masyarakat harus ditingkatkan karena akan sangat mendukung untuk memberantas korupsi di pemerintahan.

\section{Simpulan}

Berdasarkan pembahasan mengenai pengaruh temuan audit, tindak lanjut audit, opini audit, ukuran pemerintah, belanja modal, indeks pembangunan manusia yang berpengaruh terhadap tingkat korupsi pemerintah daerah, maka penelitian ini menyimpulkan beberapa hal antara lain; Pertama, temuan audit tidak berpengaruh terhadap tingkat korupsi. Hal ini dikarenakan dalam penelitian ini temuan audit termasuk temuan atas kelemahan sistem pengendalian internal yang bukan merupakan suatu pelanggaran dan tidak menimbulkan kerugian berupa materiil dalam keuangan pemerintah daerah. Kedua, tindak lanjut rekomendasi berpengaruh positif terhadap tingkat korupsi. Hal ini berarti menunjukkan bahwa semakin melaksanakan apa yang 
telah direkomendasikan oleh auditor, maka pemerintah semakin memperbaiki kesalahan dalam pertanggungjawaban penyelenggaraan negara sehingga dapat mencegah terjadinya kesalahan penyimpangan, penyelewengan dan pemborosan. Ketiga, opini audit tidak memiliki pengaruh terhadap tingkat korupsi. Opini audit tidak memiliki pengaruh terhadap tingkat korupsi di pemerintah daerah. Pemerintah provinsi yang mendapatkan opini Wajar Tanpa Pengecualian (WTP) maupun disclaimer tetap terindikasi melakukan tindak pidana korupsi. Opini audit yang baik tidak menjadi jaminan bebasnya suatu pemerintah provinsi dari korupsi. Hal ini disebabkan opini audit yang diberikan oleh Badan Pemeriksa Keuangan (BPK) hanya menilai tata kelola keuangan yang dilakukan pemerintah provinsi adalah baik dan penyajian laporan keuangannya wajar, bukan benar.

Keempat, ukuran pemerintah tidak berpengaruh terhadap tingkat korupsi. Hal ini dapat dijelaskan bahwa besarnya ukuran pemerintah tidak serta-merta dapat meningkatkan korupsi, dikarenakan ada beberapa bukti empiris juga yang menemukan hubungan terbalik dimana ukuran pemerintah yang besar dapat menurunkan korupsi. Kelima, belanja modal tidak berpengaruh terhadap tingkat korupsi. Pada variabel belanja modal semakin meningkatnya upah belanja sektor publik maka akan meningkatkan biaya dalam upaya terjadinya korupsi. Keenam, indeks pembangunan manusia tidak berpengaruh terhadap tingkat korupsi. Dengan demikian, semakin tinggi pendidikan masyarakat akan meningkatkan kemampuan pengawasan yang dilakukan, sehingga mengurangi kemungkinan terjadinya tindakan menyimpang yang dilakukan oleh aparat pemerintah daerah.

Berdasarkan hasil simpulan yang telah dikemukakan di atas, maka penulis memberikan beberapa saran yang mungkin dapat bermanfaat. Adapun saran-saran tersebut antara lain bagi pemerintah daerah sebaiknya memperkuat sistem pengendalian terkait dengan akuntansi dan pelaporan serta sistem pengendalian dalam pelaksanaan anggaran pendapatan dan belanja daerah karena kedua kelemahan ini mendominasi dalam daftar jumlah temuan audit atas kelemahan sistem pengendalian pemerintah daerah. Pemerintah daerah juga harus tetap memperhatikan tata cara atau prosedur penyelenggaraan pemerintahan agar pelanggaran administrasi dapat diminimalisir. Pemerintah daerah perlu mewaspadai adanya pelanggaran terhadap peraturan perundang-undangan selama proses penyelenggaraan pemerintahan, terutama untuk tindakan yang dapat menimbulkan kerugian negara.

Saran bagi peneliti selanjutnya diharapkan menggunakan sampel dari seluruh provinsi dan menggunakan tahun pengamatan yang lebih panjang sehingga hasil penelitian dapat merealisasikan kondisi pada seluruh provinsi di Indonesia; menambahkan variabel lain sebagai faktor yang diduga memiliki keterkaitan dengan tingkat korupsi, seperti pengungkapan laporan keuangan; serta melakukan pemisahan pada setiap variabel berdasarkan kategori agar mendapatkan hasil penelitian yang mendalam. Opini audit dapat dipisahkan menjadi WTP, WDP, WTP dengan Paragraf Penjelasan, TW dan TMP, sedangkan temuan audit dapat dipisah menjadi temuan audit atas kelemahan sistem pengendalian internal dan temuan audit atas ketidakpatuhan terhadap perundangundangan. 


\section{Daftar Pustaka}

Arifianti, H., Payamta \& Sutaryo (2013). Pengaruh Pemeriksaan dan Pengawasan Keuangan Daerah terhadap Kinerja Penyelenggaraan Pemerintah Daerah (Studi Empiris pada Pemerintahan Kabupaten/Kota di Indonesia). Paper dipresentasikan pada Simposium Nasional Akuntansi (SNA) XVI, Manado, 25-28 September 2013.

Azhar, K. \& Setyaningrum, D. (2015). Pengaruh Temuan dan Tindak Lanjut Hasil Pemeriksaan BPK terhadap Korupsi Kementrian/Lembaga di Indonesia. Universitas Indonesia. Diakses dari http://lib.ui.ac.id/naskahringkas/2018-10/S59195Khaliful\%20Azhar.

Badan Pemeriksa Keuangan (BPK). (2015). Ikhtisar Hasil Pemeriksaan Semester I.

Badan Pusat Statistik (BPS). (2016). Indeks Pembangunan Manusia menurut Provinsi, 2010-2017 (Metode Baru).

CNN Indonesia. (2016). Tingkat Korupsi Tinggi Hambat Kualitas Pendidikan. (Diakses dari https://www.cnnindonesia.com/nasional/20160518173613-20-131716/tingkatkorupsi-tinggi-hambat-kualitas-pendidikan.

Detik Finance. (2017). Kemenkeu: Korupsi Terbesar di Pengadaan Konstruksi Bangunan. Diakses dari https://finance.detik.com/berita-ekonomi-bisnis/d-3738399/kemenkeukorupsi-terbesar-di-pengadaan-konstruksi-bangunan.

Doyle, J., Ge, W., \& McVay, S. (2007). Determinants of Weaknesses in Internal Control over Financial Reporting. Journal of Accounting and Economics, 44(2007): 193-223.

Effendy, Y. (2013). Tinjauan Hubungan Opini WTP BPK dengan Kasus Korupsi pada Pemda di Indonesia Kajian Manajemen Keuangan Pemerintah, Hubungan antara Masyarakat, Pemerintah dan Pemeriksa (Auditor). Jurnal Manajemen dan Bisnis, 13(1): 46-55.

Franciari, P. S. \& Sugiyanto, F. X. (2013). Analisis Hubungan IPM, Kapasitas Fiskal, dan Korupsi terhadap Kemiskinan di Indonesia (Studi Kasus 38 Kabupaten/Kota di Indonesia Tahun 2008 dan 2010). Diponegoro Journal of Economics, 2(2): 1-14.

Ghozali, I. (2013). Aplikasi Analisis Multivariate dengan Program SPSS 21 Update PLS Regresi. Edisi Ketujuh. Semarang: Badan Penerbit Universitas Diponegoro.

Harianto, D. \& Adi, P. H. (2007). Hubungan Antara Dana Alokasi Umum, Belanja Modal, Pendapatan Asli Daerah dan Pendapatan Per Kapita. Paper dipresentasikan pada Simposium Nasional Akuntansi (SNA) X, Unhas Makassar, 26-28 Juli 2007.

Hasthoro, H. A. \& Suhardjanto, D. (2014) Karakteristik Pemerintah Daerah, Korupsi dan Kinerja Keuangan Daerah. Paper dipresentasikan pada Konferensi Ilmiah Akuntansi 1-2014, IAIKAPd Wilayah Jakarta Banten di Universitas Mercu Buana Jakarta, 26-27 Februari 2014.

Heriningsih, S. \& Marita. (2013). Pengaruh Opini Audit dan Kinerja Keuangan Pemerintah Daerah terhadap Tingkat Korupsi Pemerintah Daerah (Studi Empiris pada Pemerintah Kabupaten dan Kota di Pulau Jawa). Buletin Ekonomi, 11(1): 1-12.

Huefner, R. J. (2011). Fraud Risks in Local Government: An Analysis of Audit Findings. Journal of Forensic \& Investigative Accounting, 3(3): 111-125.

Indonesian Corruption Watch (ICW). (2015). Laporan Akhir Tahun 2015.

Indonesian Corruption Watch (ICW). (2016). Laporan Akhir Tahun 2016.

Ismunawan. (2016). Pengaruh Faktor non Keuangan dan Keuangan terhadap Tingkat Korupsi Pemerintah Daerah di Indonesia. Universitas Sebelas Maret. Diakses dari https://eprints.uns.ac.id/24956/1/S4311030_pendahuluan.pdf. 
Kejaksaan Republik Indonesia. (2015). Laporan Tahunan Kejaksaan Republik Indonesia 2015.

Kristanto, S. B. (2009). Pengaruh Ukuran Pemerintahan, Pendapatan Asli Daerah (PAD), dan Belanja Modal sebagai Prediktor Kelemahan Pengendalian Internal. Jurnal Akuntansi Ukrida Universitas Kristen Krida Wacana, 9(1): 41-62.

Kurniawan, T. (2013). Peranan Akuntabilitas Publik dan Partisipasi Masyarakat dalam Pemberantasan Korupsi di Pemerintahan. Jurnal Ilmu Administrasi dan Organisasi, 16(2): 116-121.

Kompas. (2014). KPK: Kelemahan Sistem Pelayanan Publik Jadi Celah Suap. Diakses dari

https://nasional.kompas.com/read/2014/06/03/2321553/KPK.Kelemahan.Sistem.Pel ayanan.Publik.Jadi.Celah.Suap.

Lessmann, C. \& Markwardt, G. (2010). One Size Fits All? Decentralization, Corruption, and the Monitoring of Bureaucrats. World Development, 38(4): 631-646.

Liu, J. \& Lin, B. (2012). Government Auditing and Corruption Control: Evidence from China's Provincial Panel Data. China Journal of Accounting Research, 5(2): 163186.

Lukfiarini, R. (2018). Pengaruh Hasil Audit BPK-RI terhadap Tingkat Korupsi. Universitas Lampung Diakses dari http://digilib.unila.ac.id/30322/2/SKRIPSI\%20TANPA\%20BAB\%20PEMBAHAS AN.pdf.

Mardiasmo. (2009). Akuntansi Sektor Publik. Yogyakarta: ANDI Publisher.

Masyitoh, R. D. , Wardhani, R., \& Setyaningrum, D. (2015). Pengaruh Opini Audit, Temuan Audit dan Tindak Lanjut Hasil Audit terhadap Persepsi Korupsi pada Pemerintah Daerah Tingkat II Tahun 2008-2010. Paper dipresentasikan pada Simposium Nasional Akuntansi (SNA) XVIII, USU Medan, 16-19 September 2015.

Olken, B. A. (2007). Monitoring Corruption: Evidence from a Field Experiment in Indonesia. Journal of Political Economy, 115(2): 200-249.

Peraturan Pemerintah (PP) Nomor 71. (2010). Standar Akuntansi Pemerintahan.

Rajasa, A. (2014). Analisis Hubungan Tingkat Pembangunan Manusia terhadap Tingkat Persepsi Korupsi pada Negara-Negara Anggota APEC. Jurnal Eksekutif, 11(1): 7787.

Republika. (2013). Tingkat Pendidikan di Indonesia Tak Pengaruhi Perilaku Korupsi. Diakses dari https://www.republika.co.id/berita/nasional/umum/13/11/10/mw20matingkat-pendidikan-di-indonesia-tak-pengaruhi-perilaku-korupsi.

Rini, R. \& Sarah, A. (2014). Opini Audit dan Pengungkapan atas Laporan Keuangan Pemerintah Kabupaten serta Kaitannya dengan Korupsi di Indonesia. Jurnal Etikonomi, 13(1): 1-20.

Setyaningrum, D. (2015). Kualitas Auditor, Pengawasan Legislatif dan Pemanfaatan Hasil Audit dalam Akuntabilitas Pengelolaan Keuangan Daerah. Disertasi. Universitas Indonesia: Depok. Diakses dari http://lib.ui.ac.id/file?file=pdf/abstrak/id_abstrak-20404510.pdf.

Sharma, C. \& Mitra, A. (2015). Corruption, Governance and Firm Performance: Evidence from Indian Enterprises. Journal of Policy Modeling, 37(5): 835-851.

Sugiyono (2016). Metode Penelitian Kuantitatif Kualitatif R\&D. Bandung: Alfabeta. 
Sumarjo, H. (2010). Pengaruh Karakteristik Pemerintah Daerah terhadap Kinerja Keuangan Pemerintah Daerah. Universitas Sebelas Maret:Surakarta Diakses dari https://eprints.uns.ac.id/4060/1/169923001201211261.pdf.

Transparency International Indonesia. (2016). Corruption Perceptions Index 2015. Perbaiki Penegakan Hukum, Perkuat KPK, Benahi Layanan Publik. Diakses dari http://pkppwasbang.upi.edu/2016/03/17/corruption-perceptions-index-2015perbaiki-penegakan-hukum-perkuat-kpk-benahi-layanan-publik.

Umar, H. (2012). Pengawasan untuk Pemberantasan Korupsi. Jurnal Akuntansi dan Auditing, 8(2): 95-189.

Undang-Undang Nomor 15 Tahun 2004. Pemeriksaan Pengelolaan dan Tanggung Jawab Keuangan Negara.

Undang-Undang Nomor 20 tahun 2001. Pemberantasan Tindak Pidana Korupsi.

Verawaty. (2016). Determinan Timeliness Penetapan APBD Pemerintah. Jurnal Akuntansi Multiparadigma (JAMAL), 7(3): 498-508.

Verawaty. (2017). Accountability and Internet Financial Reporting of Local Government: An Indonesia Analysis. LAMBERT Academic Publishing: Germany.

Warmer, M. W. (2012). Does Local Government Size Matter? Privatization and Hybrid System of Local Service Delivery. Working Paper International Center for Public Policy, Georgia State University, USA. Diakses dari https://icepp.gsu.edu/files/2015/03/ispwp1212.pdf.

Windarti, A. (2015). Pengaruh Anggaran Belanja Daerah dan Senjangan Anggaran terhadap Tingkat Korupsi di Indonesia. UIN Syarif Hidayatullah Jakarta. Diakses dari

http://repository.uinjkt.ac.id/dspace/bitstream/123456789/31370/1/Anissa\%20Wind arti.pdf.

Yuliana, I. \& Setyaningrum, D. (2016). Pengaruh Penerapan E-Government dan Akuntabilitas terhadap Persepsi Korupsi di Kementrian/Lembaga. Paper dipresentasikan pada Simposium Nasional Akuntansi (SNA) XIX, Unila Lampung, 24-27 Agustus 2016.

\section{Copyright Disclaimer}

Copyright for this article is retained by the author(s), with first publication rights granted to the journal. 